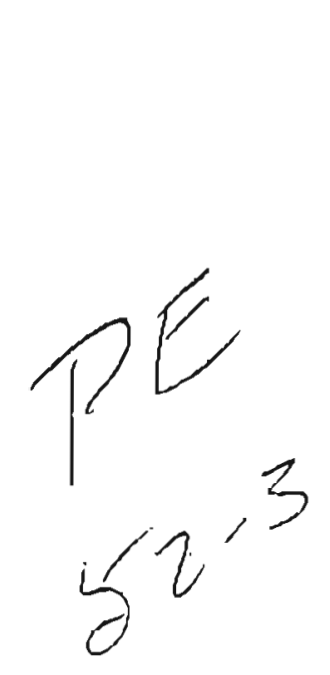

TERAITORY OF ALABKA

DEPARTMENT OF MINES

BOX 1901

JUNEAU, ALASKA

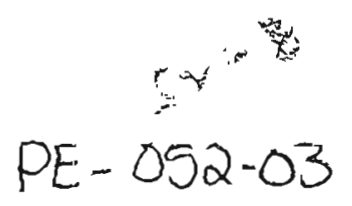

PROPERTY EXAMINATION REPORT

NATIVE BISMUTH, INC. - CHARLEY CREEK BISMUTH PROSPECT ${ }^{+} 5^{2}$

(NOMP QUADRANGLE)

By:

Puil R. Holdsworth

December - 1955

GENERAL

The property of Native Bismuth, Inc., located some 35 miles north of Nome, Alaska, was visited briefly by the undersigned on September 17, 1955, accompanied by Ignace Kowalski and Peter 0 . Sendvik. Access to the property was by car to the end of the Snake River road, and the remaining 11 miles by tractor. Five hours were spent covering all bown surface exposures and tracing the apparent extention of the vein system in a northwesterly direction. Three type samples were taken. The night was spent at the camp and the party returned to Nome the following day.

A brief report on this blsmuth prospect was made by Daniel A. Jones of the Territortal Department of Mines Nome office in 1951. Accampanying the report were two maps drawn by 0 . E. Margraf of Native Bismuth, Inc., resulting from a stadia survey made at that time. Apparently some additional surface prospecting has been accomplished since the time of the 1951 report as several new open cuts had been bullobed, on both limits of the creek, in an atternt to delimit the mineralized zone.

\title{
VEIN SYSTEM
}

The mineralized occurrence consists of several bismuth-bearing quartz veins in a schist country rock. The most prominent showing is a vein which 
has been cut by Charley Creek at an elevation of 1,040 feet. A short adit has been driven on this structure just above the creek level, but was not examined as it had been "battened up" against winter snows. This vein varies in width from 12 inches to as much as 30 inches along its exposed length. Occasionally it splits into two narrow veins separated by a few feet of country rock. Some minor post-mineral faulting has occurred, but no evidence of any great displacement was noted on the left-limit side of the creek. Readings taken with a pocket transit gave an everage strike of $\mathrm{N} 68^{\circ} \mathrm{W}$ with a dip of $50^{\circ}$ to the northeast. By following sparsely mineralized quartz float and outcrops, this main vein system was traced in a northwesterly direction for over two clajm lengths; from the Charley Creek exposure to the left-limit tributary which enters downstream. Time did not permit tracing the vein aystem beyond this point. The area on the right Ilmit of Charley Creek, directly opposite the adit and on the general strike of the main vein system, is deeply covered Wth unconsolidated material. Trenching has not been deep enough to reach rock in place. A traverse of rock in place, higher on the right-limit hillside, ald not disclose quartz velns which might be correlated with the vein structure to the west. It is quite possible that Charley Creek has eroded and is following a fault zone which has displaced the eastward extension of the vein system a considerable distance.

Three samples were takea along the major vein system. Sample No. 1 was taken across a 12-inch quartz vein exposed in the highest (most westeriy) cut on the left limit of Charley Creek. This was apparently the hangiag wall. vein of two peralzel veins separated by several feet of schist country rock, and was the more mineralized and persistent of the two. The sample was taken in an area which appeared to represent average mineralization of this structure. 
Sample No. 2 was composed of six inches of both footwall and hanging wall country rock, immediately adjacent to the vein quartz at this same general locetion. Sample No. 3 was cut across a 12-inch quartz vein cut by Charley Creek along the same general strike and apparent vein structure. The sample was purposely cut across an apparent high-grade (or heavily mineralized) zone in the vein. Sarmle results are tabulated below:

\begin{tabular}{|c|c|c|c|}
\hline & Gold & Silver & BIsmuth \\
\hline No. 1 & $0.04 \mathrm{oz}$ & nil oz. & 0.23 o \\
\hline No. 2 & - & - & $0.01 \%$ \\
\hline No. 3 & $0.060 z$. & $0.20 \mathrm{oz}$. & $3.03 \%$ \\
\hline
\end{tabular}

In addition to the above mentioned vein system, another area of interest was noted high on the billside on the left limit of Charley Creek and almost due south of the adit portal. An open cut, at an elevation of 1,370 feet, has exposed a quartz vein apparently "In place". Some minerallzation was noted here, but large well mineralized pieces of quartz float were traceable down-bill from this cut in the general airection of Charley Creek. One plece of float in particular was about four feet in diameter and was well mineralized. The hillside in this area appears to be rell broken up and covered with unconsolidated material. It will take consioerable work to determine the size and extent of this showing.

\section{CONCLUSIONS}

This prospect is an extremely interesting and rare mineral occurrence. Bismuth is becoming a more important metal each year. A full mining width of one percent material, or its equivalent, must be developed before a profitable operation is indicated if the location of the prospect and present economic conditions are taken 1nto account. 
Th1s :- prospect of Native Bismuth, Inc. Is like many others in Alaska; enough is known about it to make it interesting, but a thorough exploration program must be conöucted before a development program is justified. Geologicaliy, the area is promising not only for bismuth, but for tin and tungsten. The associated gold values also add to the general picture. A thorough geological reconnaissance, followed by geochemical soil sampling, might disclose the structural pattern of the vein system and indicate the location of mineral conceatrations.

Again, like other prospects in the Territory, the owners are not in a position to carry out the suggested type of exploration program. The future of the prospect depends on fust how serlous establiahed mining compantes are in their expressed desire to develop new mineral resources.

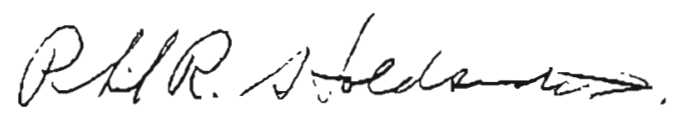

Ph1I R. Holdsworth Cormissioner of Mines

PRH'com 